\title{
PHYSICAL CULTURE IN SOMATIC HUMAN BEING
}

\section{ФІЗИЧНА КУЛЬТУРА В СОМАТИЧНОМУ БУТТІ ЛЮДИНИ}

\section{Gazniuk Lydiia ${ }^{1}$ \\ Semenova Julia ${ }^{2}$}

DOI: http://dx.doi.org/10.30525/978-9934-571-27-5_11

\begin{abstract}
This work is devoted to the consideration of the phenomenon of physical culture and sport through the understanding of the somatic being of modern humans. The subject of the study are some aspects of physical culture and sports as a social institution, the functioning of which depends on the attitude of society and culture to human corporeality, the value of the body and health. As a methodology, a philosophical-anthropological approach is used that combines modern philosophical and cultural theories.

The purpose consists of the analysis of the significance and functions of physical culture, sport and physical education in the physical existence of man in modern society. It is determined that in the understanding of the notion of physical culture and sports there is a one-sided attitude that does not take into account the spiritual, cultural and moral content of bodily activity, which is invariably formed in the process of incorporating the existence of corporeality into the structure of socio-cultural values, norms and ideals.

The authors argue that understanding the value of physical culture changes the attitude of the society towards physical education. Physical culture gets a new meaning; it must become a way of preserving physical activity, improving health and maintaining the quality of life. The modern system of physical training of a person as a part of physical culture and recreational activity in general should be a special complex of socio-economic, political, legal, environmental, cultural and educational and other measures aimed at preserving and improving health, increasing the level of physical development and physical fitness of people.
\end{abstract}

\footnotetext{
${ }^{1}$ Grand PhD in Philosophical Sciences, Professor, Head of the Department of Humanities,

Kharkiv State Academy of Physical Culture, Ukraine

${ }^{2} \mathrm{PhD}$ in Philosophical Sciences, Associate Professor,

Dean of Faculty of Physical Education and Human Health,

Kharkiv State Academy of Physical Culture, Ukraine
} 


\section{1. Вступ}

Існування сучасної людини внаслідок постійних трансформацій суспільства, а разом $з$ цим моралі, ціннісних орієнтацій, сенсо-буттєвих поглядів тощо, вимагає від суспільних наук пошуку нових шляхів до вивчання, дослідження та аналізу різних аспектів людського буття. Саме тому за предмет нашого дослідження обрано фізичну культуру і спорт як унікальні соціальні явища, що розглядаються нами крізь призму соматичного буття особистості. Це поняття ще тільки входить у широкий обіг представників філософських і суспільних наук, тому його детальне вивчення та аналіз постає дуже актуальним.

Застосування філософсько-антропологічного підходу до вивчення впливу фізичної культури на соматичне буття людини здається найбільш дієвим й ефективним, оскільки охоплює практично всі грані людського буття. Ймовірно, саме такий підхід корелює з реальною соціокультурної основою буття людини, припускаючи облік як універсальних екзистенційно-буттєвих характеристик людини, так і різноманітності психофізіологічних властивостей антропологічних типів, які можуть належати до одного соціуму, однієї культурі.

\section{2. Феномен соматичного буття людини}

Універсальний дискурс про людину складається з різноманіття практик та їх самоопису, де є місце не тільки умовному, але й безумовному, не тільки відносному, але і абсолютному. Цілісне персонально-соматичне буття людини включає у собі кілька складових. Людина може розумітися як: дух-душа-тіло; розум-воля-почуття; свідоме-несвідоме; духовне-психологічне-біологічне; вічна душа і кінцеве тіло; тілесні форми-відчуття-свідомість.

Поняття «сома», «соматичне» з'явилося в зарубіжній літературі не так давно, але до цих пір не зайняло належного місця в вітчизняних філософських дослідженнях. Новий філософський словник Дідьє Жюма розглядає поняття «соматичний» як той, що стосується тіла, проте в перекладі з грецького soma - тіло, але не просто матеріальний об'єкт, а жива одухотворена істота. Поняття «людина соматична» постає як особлива реальність, в якій взаємодіють різні сфери іії буття.

Персональне соматичне буття в своєму життєвому самовизначенні поєднує природність і розумність. Філософське питання «що $є$ людина?» стосується не стільки предметних характеристик людини, 
скільки умов, в яких їх реалізація стає можливою, які підпадають під номінацію буття. Феноменологічний метод являє собою своєрідну серцевину філософської антропології. Реальне буття людини неможливо звести до схематичної конструкції, а тому вважаємо за доцільне в якості робочої гіпотези прийняти «синтетичну» концепцію, де поєднувалися б риси підходів, які є складовими сучасного світу і інтерпретують людське буття. Персональне соматичне буття «унікально-інше», кожна людина $є$ автономною істотою, здатною відчувати і переживати, прагнути до комунікації, пізнання світу і зміни власного буття. У процесі комунікації людина ризикує потрапити в граничну ситуацію, що може призвести до втрати екзистенції й самого буття. Зрозуміло, що все, на що здатна людина, далеко не завжди реалізується в персональному бутті людини, оскільки усі люди різні, й якщо в антропологічної визначеності одного домінують вольові фактори, то в іншого - раціональні.

Філософські роздуми щодо персонального буття охоплюють людину в її комунікації з іншими людьми, з ії̈ практикою соматичного, де мають місце екзистенційні переживання, в яких самореалізується людина [2]. Тому стає необхідним як звернення до екзистенційних глибин людського буття, так і до соціокультурного просторово-часового континууму, де здійснюється персональне соматичне буття в переживанні й проживанні життя. Слід, перш за все, поставити питання про персональність переживань людини і про те, як вони позначаються на iii соматичному бутті. Людина несе в собі цілий світ, внутрішній всесвіт, який пов'язаний з зовнішнім Всесвітом. Конструктивні акти, які надані людині, є не просто результатом її біологічної життєдіяльності, але актом екзистенційно-соматичного переживання i проживання життя. Пограничность буття і постійне перебування в прикордонній ситуації не можуть не позначатися на соматичному стані людини. Унікальними для переживань, що формують соматичну пам'ять, є прикордонні ситуації на межі фізичного виживання.

\section{3. Фізична культура як різновид соматичної субкультури}

Інтерес до соматичних явищ в нинішній час спостерігається у представників самих різних наукових дисциплін і професій - у біологів, медиків, працівників сфери фізичної культури і спорту, психологів і філософів. Соматична культура - це синтетичне поняття, яке включає в себе моральну, інтелектуальну, психічну, фізіологічну складові. 
Високий рівень соматичної культури є показником здоров'я людини, який останнім часом катастрофічно падає.

Одним з головних шляхів зміцнення здоров'я є фізична культура. Саме культура, тобто не просто ранкова гімнастика і випадково зіграна партія в волейбол, а розумне, одухотворене ставлення до свого тіла, прагнення до фізичної досконалості, гармонії і краси. Необхідно багато і цілеспрямовано працювати для закріплення звички здорового способу життя і діяльності людей, включаючи здоров'я і фізичний розвиток як його компоненти [1].

Соматичне буття людини і потенції пї розвитку знаходяться в складній залежності від стану суспільних відносин і способу життя людей. Фундаментальна медицина накопичує все більше даних про те, що рівень здоров'я індивіда і груп людей безпосередньо залежить від ступеня їх участі в матеріальній та духовній діяльності і особливо в тих видах діяльності, які носять творчий, стимулюючий характер. Стає очевидним, що в практиці суспільного життя і у феноменах індивідуального існування людини виявляються нові вузли протиріч тілесної і духовної організації людини, які й визначають рівень соматичної субкультури. Фізична культура як різновид соматичної субкультури виступає специфічною характеристикою предметної діяльності людини, спрямованої як на світ навколо себе, так і на саму себе, що надає цьому феномену суб'єктивного і одночасно об'єктивного характеру. Змінюючи навколишній світ, людина довільно модифікує і свою тілесну організацію і соматичний стан в цілому.

Соматична субкультура є характеристикою цієї системи взаємодії природних і соціальних якостей людського тіла в процесі життєдіяльності, надає їй статусу специфічної предметності і матеріальності, субстратності людини. Це поняття характеризує спосіб соціального буття людського тіла, тобто соціального опосередкованого протиріччя індивідуального тіла і духу людини, як персонального соматичного буття. Головне для розуміння специфіки соматичного в людині полягає в 3'ясуванні його чуттєво-надчуттєвого характеру, що робить його феноменом культури людини. Соматичне включає всю людину, тобто з їі психікою, розумовими можливостями і персональними особливостями.

Природно-речові характеристики тіла-соми, які вивчаються комплексом медико-біологічних дисциплін, не визначають специфіку 
людини, оскільки остання проявляється в чуттєво-надчуттєвих відносинах в процесі життєдіяльності.

Соціальний спосіб буття соми як єдино можливий, є одночасно й культурним феноменом, якщо культуру не зводити до речових характеристик, а розуміти як щось об'єктивно притаманне речі або тілу, і в той самий час воно вимагає особистісного цілеспрямованого культивування. Воно нерозривно пов'язане 3 цілепокладанням, з ідеалами і шляхами їх досягнення, тобто вимагає врахування впливу індивідуальної суб'єктивності. Це в свою чергу визначає типи ставлення суспільства до явищ тілесної організації та тілесних функцій людини, які узагальнюються соматичної субкультурою. Дана специфіка відбивається на загальному інтелектуальному тлі, який сформувався завдяки, перш за все, формам духовно-практичного освоєння світу, таким як міфологія, релігія, мистецтво, моральна свідомість. Для них в цілому характерно синкретичне уявлення про людину, тобто соматичне виявляє протиріччя тіла і духу на різних етапах життя людини.

Однією зі сфер діяльності людини, спрямованої на виявлення максимальних фізичних, а в деякій мірі і психічних можливостей людини є фізична культура і спорт. Спорту притаманний змагальний характер діяльності та ігрове за формою, позбавлене утилітарності по цілі дійство. Ще давньогрецький філософ Ксенофан, відстоюючи утилітарний підхід до життя, заперечував важливість і не бачив користі від Олімпійських ігор [4]. У заняттях спортом саме фізичні якості виступають об'єктом взаємодії. Серед великої кількості визначень культури в більшості з них iї трактують лише як внутрішню духовну культуру. Питання про соціокультурний статус тілесних характеристик і фізичних параметрів людини, а також проблема специфіки «окультурення тіла» і зв'язку цього процесу з духовним розвитком залишаються без уваги. Природно-фізичні якості людини з самого початку не існують поза соціокультурним контекстом, в рамках якого їх значення тільки i може бути зрозуміле і оцінене. Але насправді не існує деякої абстрактної фізичної природи і соціально-обумовленої духовності.

Певною мірою винесення тілесно-фізичних якостей людини за межі філософсько-культурологічного аналізу - це продовження і відображення платонівської лінії, а також християнських традицій, з їх зневажливим ставленням до всього, що пов'язане з тілесним початком в людині, як до чогось низького, непристойного, що не заслуговує до 
себе уваги. Ці принципи, які закріплювалися віками, безумовно, дали про себе знати у ставленні до фізичної культури і спорту, відбилися на їх статусі у порівнянні з іншими елементами культури суспільства і особистості. На початку XXI століття дослідницький інтерес широкого кола фахівців в галузі фізичної реабілітації, фізичної культури і спорту пов'язаний $з$ новітньою технікою, сучасними технологіями i біосоціальними практиками, які принесли людині зручності і комфорт, проте разом з ними зменшення фізичного навантаження і гипокінезію.

Питання про місце і значення соматичної субкультури, пов'язаної 3 тілесно-фізичними якостями людини, є дуже важливим в процесі формування цілісної особистості, який є частиною більш широкої проблеми зв'язку і взаємодії культури і природи, рішення якої передбачає аналіз системної єдності відповідних елементів на різних рівнях. Серед них слід виділити екологічний рівень: «людина - довкілля», антропологічний рівень: «біогенетичне - соціокультурне в людині», планетарний: «суспільство - природа», вселенський: «біосфера - техносфера».

У соматичної субкультурі важливим $є$ антропологічний рівень, який вказує на те, що тілесно-фізичні якості людини не є тільки власне природним початком, вони не тотожні їх суто біологічному змістові. В процесі розвитку багато чинників соціокультурного характеру виявилися важливими для формування не тільки духовно-психічних якостей людини, але й іiї тілесної організації. Духовність в людині теж не може бути розглянути як сверхвітальная.

Рівень соматичної субкультури в значній мірі визначається тими умовами, які надає суспільство для розвитку людини, вони можуть бути актуалізовані індивідом лише в тому випадку, коли його фізичний стан найбільш «кондиційний» для процесу розвитку, коли він забезпечує максимальну життєздатність, повноту прояву емоційних, інтелектуальних і всіх творчих сил людини. Розвиток особистості, як процес залучення в світ культури, неможливий без такої її суттєвої частини, як соматична субкультура індивідуальності.

Фізична культура, будучи різновидом соматичної субкультури, включає в собі соціально сформовані фізичні якості і здібності людини, а також ту соціальну реальність, яка забезпечує їх формування та розвиток, в тому числі відповідні елементи ціннісно-мотиваційної структури особистості, які містять установку на формування 
і вдосконалення цих якостей, стандарти поведінки і ідеали фізичної досконалості, які пропагуються, а також соціальні інститути, які керують даними процесами [5].

Удосконалення фізичних якостей стає соматичною субкультурою тільки за умови, що воно має сенс не чисто фізичного, але особистісного розвитку, а тому перетворення тілесного вдосконалення, здоров'я в самоціль навряд чи можуть бути віднесені до феномену культури взагалі і соматичної субкультури зокрема. Соматична субкультура, як гармонія духу і тіла, усвідомлювалася як вищий сенс ще древніми греками. Наблизитися до цієї гармонії означало реалізувати дійсно гуманістичні початку в суспільному житті.

\section{4. Соматичне буття у сучасному спорті.}

Спорт - це демонстрація граничних можливостей людини. Одна 3 найяскравіших тенденцій в розвитку сучасного спорту - це тенденція суто технократична, для якої характерне перенесення мети діяльності з людини, їі власного розвитку на результат. Голи, очки, секунди, місця і медалі в технократичній системі цінностей, в якій людина опиняється тільки засобом, перетворюються на самоціль, стають самоцінними. Гіпертрофований фізичний розвиток за рахунок інтелектуального, духовного, бажання залучити будь-які заходи (допінг, анаболіки, жорстокість тощо) заради перемоги, повне використання потенціалу юного спортсмена, а потім залишення його напризволяще - все це прояви технократизму, яке досить антигуманні за своєю суттю і формою.

О. Шпенглер відносив спорт до парадигм цивілізації, проте не культури. По-справжньому гуманне суспільство не може й не повинно приносити на вівтар спортивного прогресу здоров'я, гармонійний розвиток, моральні цінності людини. Реальне здійснення девізу «У розвиненому тілі - піднесений дух», який висунув Кубертен, вимагає від суспільства пошуку таких механізмів, які б дозволяли протистояти антигуманізму і жорстокому прагматизму в спорті.

Як і кожен вид діяльності, кожен вид спорту ставить певні вимоги до людини, яка ним займається, в тому числі й до морфології іiі тіла. Формуються певні стереотипи відповідності між видами спорту і антропометричними даними. Одним з аспектів спортивної діяльності $€$ формування тілесної краси і рухів людини. Тілесна краса передбачає стрункість, підтягнутість, симетричність, пропорційність, гар- 
монійність тіла людини. Ще в Стародавній Греції було доведено, що заняття спортом, використання різних фізичних вправ дозволяє надати тілу людини більше виразності і краси. Яскравим свідченням цього є класична фігура «Дискобол» Мирона, «Списник» Поліклета, «Метальник» Алкаменеса та інші твори давньогрецького мистецтва.

Залежно від соціальних відносин, спорт може не тільки не мати за мету фізичну досконалість, але він здатний і просто спотворити людську подобу в залежності від того, яку мету перед ним ставлять, і в якій системі соціальних цінностей він орієнтований. Якщо грецьке мистецтво класичного періоду дає нам образ гармонійного розвитку людини - громадянина, воїна, атлета, зовсім іншим описаний Феокрита (III в. до н.е.) портрет кулачного бійця-професіонала елліністичної епохи - часу, коли спорт став перетворюватися на форму заробітку, на засіб існування.

Вузькоутилітарні мети, технічні результати, комерційні міркування в спорті призводять до вихолощування гуманістичного ідеалу, в меншій мірі служать розвитку особистості та іiі фізичної досконалості. Спорт впливає на інтелектуальну, пізнавальну можливості людини, допомагає глибше пізнати закономірності, яким підпорядковується формування фізичної досконалості, розвиток фізичних якостей і вмілих рухів та навичок, які набувають важливого значення в структурі та функціях організму, вказують на причини і механізм фізичного розвитку, свідчать про суспільну і особисту гігієну. Спортсмену властиво оперативне мислення, коли інтелектуальні завдання вирішуються безпосередньо в процесі діяльності, спираючись на сприйняття об'єктивних умов і ситуацій, в яких це відбувається, при значному дефіциті часу.

Одним 3 проявів соматичної субкультури є рух культуризму "bodybuilding" (тілобудування), а точніше штучне конструювання м'язів. Культуризм дає можливість досягнення швидких і ефективних результатів для зміни форм м'язів, об'єму грудей і інших параметрів людського тіла. Але культуризм не дає людині істинної краси, не формує навіть тілесну красу в повному розумінні цього слова. Справа в тому, що в культуризмі цінуються тільки м'язи, а точніше їх зовнішній вигляд. Але «накопичення» м'язів і пов'язаної з ними сили у відриві від формування таких цінних фізичних якостей, як витривалість, спритність, швидкість, не призводять до гармонійного фізичного роз- 
витку людини. Слід зазначити і негативний вплив культуризму, який він здійснює на психіку і моральність тих, хто їм активно займається. Постійно «накачуючи» м'язи, щоб бути першим серед інших в позі, культуристи схильні до самозамилування, весь час акцентують увагу на свою зовнішність, виставляють на показ свою силу м'язів. Для досягнення дійсно гармонійного фізичного розвитку необхідне застосування різноманітних фізичних вправ, заняття найбільш підходящим видом спорту. Такий шлях дозволяє розвивати не тільки силу м'язів, але і спритність, витривалість, швидкість і інші фізичні якості людини, а також красу іiі рухів.

Досягнення точності, свободи, легкості, узгодженості та ритмічності характеризують координаційні здібності людини і надають естетичну свідомість рухам іiі тіла. Без краси рухів неможлива краса людини взагалі. Легкість і невимушеність рухів виглядають в людині чарівними, так як можливі тільки при добре складеній стрункості: у людини невдало складеній, як правило, відсутня красива хода, пропорційність в рухах, тому легкість і грація рухів - ознака вірного стрункого розвитку в людині.

Досконалість фізичного розвитку людини характеризує фізичну, тілесну красу. У різні історичні епохи змінюється саме поняття фізичної досконалості та іiі значущості в суспільному житті. Якщо в епоху античної демократії фізична досконалість розглядалась як необхідна умова виховання воїна і громадянина, то в період розпаду рабовласницького суспільства 3 появою найманого війська воно втрачає важливу роль застосування до громадян. Християнська доктрина аскетизму протягом декількох століть визначала суспільну свідомість, ще більшою мірою виключала вимоги фізичної досконалості людини.

Фізична досконалість висловлює певні уявлення про тілесну красу, пластичну свободу і здоров'я людини, що свідчить про рівень розвитку соматичної субкультури. Субстрат людини - це іiі тіло в поєднанні природних і соціальних якостей, тобто «людська біологія», яка знаходиться в саморуху і саморозвитку. Життєвий цикл людини в цьому відношенні може розглядатися як процес розв'язання суперечностей щодо природних і соціальних якостей субстанції тіла. Його не можна розуміти однозначно і механічно, як безперервне наростання соціальності і підпорядкування біологічного в людині соціальному. Навіть природжений тілесний дефект людини стає дефектом особистості 
саме в силу тієї чи іншої соціальної детермінації. Тільки для людини характерно активне ставлення до свого тіла, виходячи за межі «тваринної зв'язаності», сверхсітуатівна поведінка, навіть всупереч природним можливостям.

Прикладом цього може бути параолімпійський спорт, який в сучасному світі досяг рівня паралімпійського руху. Завдяки заняттям спортом люди з тілесними дефектами можуть змінити своє життя, зробити його осмисленим і яскравим. Але спорт вимагає від людей особливої сили волі, мужності і витривалості. Людина здатна піднятися над своїм тілом, вона може зробити те, чого не може жодна тварина. Іноді просто заради якоїсь мети людина може знехтувати своєю небезпекою і навіть життям. Існує дивна річ: людина може до кінця своїх днів не помічати і не відчувати свого тіла, подібно повітрю, яким ми дихаємо, і згадувати про нього тільки коли хворіє.

Соматична субкультура на внутрішньому індивідуальному рівні являє собою, таким чином, специфічну технологію процесів вирішення протиріч цієї сфери, в результаті чого досягається певний рівень людської свободи в ставленні до тіла. Досягнення певного рівня свободи, «оволодіння» своєю тілесною організацією завжди має певний соціальний і моральний вектор, який визначає соматичну субкультуру.

\section{5. Роль фізичної культури і спорту як соціального інституту в сучасному суспільстві}

Фізична культура, що включає в свою структуру спорт, є органічним компонентом загальної культури. Поняття культура об'єднує всі створені людиною в ході історії соціальні, матеріальні, духовні засоби iiі життєдіяльності, iї складові структурні елементи. До соціальних засобів в даному визначенні культури відносяться праця, культура праці і форми іiі організації; соціальні інститути: держава і право, економіка, політика, наука, освіта, соціально-культурна сфера та охорона здоров'я. Сюди ж відноситься фізична культура, структура якої визначається як матриця загальної культури, основним елементом якої є людина.

Сучасні інформаційно-комунікаційні технології активно впроваджуються в сферу повсякденної людської життєдіяльності, в тому числі в галузь фізичної культури і спорту. Перш за все, вони полегшують роботу з орієнтування молоді та мас населення на заняття фізичною культурою і спортом, як історично визнаної в суспільстві цінні- 
стю в структурі здорового способу життя. У соціально-філософському аспекті важливо підкреслити, що передумовою виникнення фізичної культури є праця, взаємодія людини з природою, добування їжі полюванням, скотарством, землеробством, вимагали не тільки фізичного i психічного здоров'я, але і спритності, сили.

Спорт в рамках фізичної культури виникає на зорі цивілізації 3 універсальної властивості людини - змагальності, вічного прагнення зайняти першість в конкуренції з суперниками. В сучасних умовах разом узяті фізична культура і спорт в історичній свідомості і способі життя народів $є$ загальновизнаним соціальним інститутом. Що стосується специфіки спорту в умовах сучасної цивілізації, то для частини населення він виступає в якості оздоровлюючого фактора в формі дозвілля, відпочинку, розваги, для невеликої соціальної групи він $є$ професією, повсякденною роботою в формі професійного спорту.

У світі спостерігається стійка тенденція підвищення соціальної ролі фізичної культури і спорту. Вона проявляється через:

- підвищення ролі держави в підтримці розвитку фізичної культури і спорту, громадських форм організації і діяльності в цій сфері;

- широке використання фізичної культури і спорту в профілактиці захворювань і зміцнення здоров'я населення;

- продовження активного творчого довголіття людей;

- організацію дозвілля як особливого виду діяльності і в профілактиці асоціальної поведінки молоді;

- використання фізичної культури і спорту як важливих компонентів морального, естетичного та інтелектуального розвитку учнівської молоді;

- залучення до занять фізичною культурою і спортом працездатного населення;

- використання фізичної культури і спорту в соціальній і фізичної адаптації інвалідів, дітей-сиріт;

- різке збільшення зростання доходів від спортивних видовищ i спортивної індустрії;

- зростаючий обсяг спортивного телерадіомовлення і ролі телебачення в розвитку фізичної культури і спорту та в формуванні здорового способу життя;

- розвиток фізкультурно-оздоровчої та спортивної інфраструктури з урахуванням інтересів і потреб населення; 
- різноманіття форм, методів і засобів, що пропонуються на ринку фізкультурно-оздоровчих і спортивних послуг.

Розвиток фізкультури і спорту в сучасному суспільстві $є$ питанням першочергової важливості, тому що здоров'я людей у вирішальній мірі визначається рівнем розвитку фізичної культури і спорту. Сучасна система фізичного виховання включає комплекс профілактичних і гігієнічних заходів, спрямованих на всебічний розвиток і збереження на довгі роки фізичної працездатності і рухової активності людей.

Однією з пріоритетних цілей суспільства, де дбають про людину, $є$ створення умов для зміцнення її здоров'я шляхом розвитку інфраструктури спорту, популяризації масового і професійного спорту (включаючи спорт вищих досягнень) і залучення різних верств суспільства до регулярних занять фізичною культурою і спортом. Фізичний стан i здоров'я населення будь-якої країни є найважливішим критерієм iii благополуччя. На початку XXI століття соціальний і техногенний розвиток суспільства почав все більш характеризуватися динамічним прогресом комунікативних можливостей, які призвели до зміни характеру соціальних зв'язків, але в той самий час, і зниженням природних, фізичних і психічних якостей людини. Світовий досвід показує, що засоби фізичної культури і спорту мають здатність в комплексі вирішувати проблеми підвищення рівня здоров'я населення та формування здорового морально-психологічного клімату в колективах і в суспільстві в цілому. Розуміння того, що майбутнє країни визначається здоров'ям членів суспільства, призвело до посилення ролі фізичної культури і спорту.

Активно використовуючи різноманітні фізичні вправи, людина покращує своє здоров'я, фізичний стан і підготовленість, фізично вдосконалюється. Ступінь фізичної досконалості визначається тим, наскільки міцну основу вона являє для подальшого розвитку, в якій мірі вона відкрита новим якісним змінам і створює умови для переходу особистості в іншу, більш досконалу якість.

У числі факторів, що формують здоровий спосіб життя, головним є фізична культура. Рухова культура - це вміння сприймати рух як символ прекрасного, природного, вільного способу самовираження, взаєморозуміння і співіснування в просторі тіл: наявність правильної постави, способів самостійного накопичення свого рухового досвіду і використання його для попередження захворювань. Оздоровчий потен- 
ціал фізичної культури і масового спорту, якщо його використовувати повністю, дозволить забезпечити стійке підвищення працездатності, запобігати масових захворювань і прагнути до збільшення тривалості життя. Фізична культура є природним містком, що дозволяє з'єднати соціальне і біологічне в розвитку людини. Більш того, вона є найпершим і базовим видом культури, який формується в людині. Фізична культура $з$ притаманним їй дуалізмом духу і тіла, може мати значний вплив на стан організму, психіки, соціокультурний статус людини.

\section{6. Фізичне виховання як фактор формування здоров'я людини}

Фізичне виховання є важливим чинником формування здоров'я в умовах сучасної постіндустріальної інформаційної цивілізації, багато в чому визначаючи поняття «стиль життя», «уклад життя», «рівень життя», «якість життя» в контексті «здорового способу життя». Фізичне виховання набуває нового значення, воно повинно стати способом збереження фізичної активності, зміцнення здоров'я та забезпечення якості життя, яке в даний час визнається однією з головних характеристик суспільства. Фізичне виховання і спорт в естетичному плані здатні покращувати тіло людини шляхом науково обгрунтованих вправ, вірного харчування, здорового способу життя.

Соматичне буття людини з урахуванням соціального та культурного різноманіття світу включає культуру рухів, культуру статури i культуру фізичного здоров'я. Фізичне виховання в соматичному бутті людини має соціально-економічне значення, воно сприяє збереженню і зміцненню здоров'я людей, зниженню рівня захворюваності людей, підвищенню продуктивності їхньої праці [3]. Стан здоров'я обумовлює якість життя індивіда в психофізіологічному аспекті, в аспекті задоволення вітальних потреб, а також забезпечує соціально-статусне розвиток. Безумовно, і соціально-виробнича сфера виграє у випадку, якщо члени суспільства менше хворіють і можуть ефективно працювати, збільшуючи валовий суспільний продукт. В умовах сучасної цивілізації величезні можливості відкриваються для пропаганди фізичного виховання і спорту з метою зміцнення міжнародних відносин. Комп'ютерна, комунікаційна техніка і високі технології в нинішній час представляють широкі можливості в дослідженні глибинних таємниць людського організму і формують наукову основу для розробки масових фізкультурно-оздоровчих заходів і програм фізичного виховання. 
Фізичне виховання і спорт в способі життя людей існують і служать зміцненню здоров'я кілька тисяч років. У суспільно-історичній свідомості вони давно прийняті як явище загальної культури людей і визнані соціальним інститутом, утвердившись в статусі цінностей культури. Разом з тим, рівень цивілізації, поряд з потужною прогресивною інтенсифікацією суспільних відносин, ставить людину перед новими проблемами. Перш за все, зростають темпи життя, завдяки сучасному транспорту скорочується соціальний простір, спресовується соціальний час, він протікає швидше. Люди поспішають, щоб не втратити час, при цьому помітно посилюється психічна і інтелектуальна напруга. У соматичному бутті людини фізичне виховання здатне зменшити цю напругу.

Сучасна медицина створила цілком ефективну систему лікувальної фізкультури, експериментально обгрунтовані наукові концепції реабілітації захворювань, допомоги інвалідам. Однак сфера фізичної культури і спорту як соціальний інститут не можуть функціонувати в якості фактора здоров'я людей без відповідної матеріально-технічної бази і підготовки кадрів для фізичного виховання молоді, спеціального оздоровчого обслуговування населення. Сучасний малорухливий спосіб життя - гіподинамія - $є$ наслідком суперечності між потребою в генетично обумовленому обсязі необхідних для нормальної життєдіяльності організму людини фізичних рухів та їх реальним задоволенням, малорухливим способом життя і необхідною фізичною активністю людей. Для багатьох людей саме тут слід шукати причини багатьох хвороб i, як результат, - передчасної смерті. Встановлено, що в багатьох випадках недостатній фізичний розвиток, слабка фізична підготовленість, фізична детренированность організму стають безпосередньою або опосередкованою причиною різних хвороб.

Сучасна цивілізація, таким чином, ставить перед суспільством, перед людством в цілому і перед кожною особистістю все зростаючі вимоги до фізичної, психічної, інтелектуальної, освітньої підготовки, і тому фізичне виховання і спорт повинні стати невід'ємною частиною способу життя кожної людини.

Філософію цікавить і аксіологічна сторона фізичної культури, тобто ставлення до неї як до цінності. Перша ціннісна сторона їі - це, звичайно ж, оздоровча, яка зберігає і зміцнює здоров'я людини, іiі життя. Тільки добре здоров'я дає повноту життя. Як жити довго, залишаючись 
здоровим? Це найбільш неоднозначна і складна проблема як для біологічних, медичних, так і для соціально-гуманітарних наук.

Сучасний рівень цивілізації приносить людині нові проблеми, для вирішення яких потрібні фізичне і духовне здоров'я. У трудовій діяльності людини зменшується частка фізичного і збільшується частка психічного та інтелектуального напруження. Як субстанція соціального, свідома діяльність, і фізична і розумова, спрямована на перетворення навколишньої дійсності для задоволення життєвих потреб людини, однією з яких є потреба в рухах. Заняття фізичною культурою сприяють закріпленню корисних для здоров'я рухів тіла, розвитку імунітету, підвищенню стресостійкості, опірності організму шкідливим впливам навколишнього середовища, а отже, оздоровленню людини.

До якісних характеристик здоров'я людини відноситься також естетична сторона тілесної організації людини. Естетика - традиційний розділ філософії, що вивчає закони предметно-чуттєвого сприйняття людиною тих явищ і процесів, що відбуваються через такі категорії, як прекрасне і потворне, піднесене і нице, трагічне і комічне. Іншими словами, зміст і сутність речей естетика бачить через їх форми. Фізична культура і спорт здатні формувати красу людини як цінність, якщо кожен індивід в своєму способі життя гармонійно поєднує заняття фізкультурою і спортом з медичної та інтелектуальної культурою.

Соматична фізична культура і культура рухової активності індивіда рідко стають центральними об'єктами соціокультурних досліджень, однак деякі аспекти даної проблематики досить часто фігурують в дослідницьких теоріях соціальної спрямованості. Увага загострюється, в основному, на факті фізичної досконалості як необхідного аспекту всебічно розвиненою і гармонійної особистості. Дана тема є константою, простежується протягом всієї історії ідеологічно забарвленою філософії: від авторів періоду античності і перших утопістів Нового часу до авторів офіційних ідеологічних документів XX століття. У сучасній інтерпретації фізична культура часто розуміється, по-перше, як усе матеріальне середовище, яке сформоване і трансформоване людиною відповідно до потреб, цінностей і можливостей (у випадках такого вживання даного поняття можна сказати, що термін «фізична культура» розширюється до терміна « культура «в цілому). По-друге, фізична культура може розглядатися як система цінностей, діяльності та іiі результатів, що мають відношення до безлічі видів 
фізичної активності людини (спортивні практики, праця, відновлення здоров'я і т.д.). По-третє, фізична культура може мати і більш вузький розгляд - як комплекс різних типів моторики, інтегрованих в різні види соціальної діяльності (в т.ч. в процеси соціалізації, навчання, оволодіння різними вміннями практичного характеру). По-четверте, фізична культура може розглядатись як набір вправ, необхідних для модифікації тілесної природи людини. По-п'яте, фізична культура розуміється як спортивна діяльність, яка характеризується змагальністю, конкуренцією, а також виявленням максимальних можливостей людини. Слід зазначити, що останнє трактування фізичної культури привнесло в масову свідомість звуження сприйняття фізичної культури до області специфічної діяльності, єдиним смисловим наповненням якої є вдосконалення фізичних якостей, навичок і умінь людини. Історично людське тіло усвідомлювалася як значущий феномен (або медіум комунікації) для вбудовування особистості в соціальний простір. При цьому обов'язково формувався культурний принцип співвіднесення тілесного і духовного в особистості (від прямої залежності до протилежності); також культура формувала значущості для кожної тілесної характеристики людини. Таким чином, формувалася система аксіології тіла як одного з фундаментальних підстав культури.

Аксіологічний підхід до фізичної культури, який утвердився в історії світової культури, спростовує тривіальну повсякденну редукцію поняття фізичної культури до системи рухової активності і розвитку суто тілесних якостей у відриві від морального, інтелектуального, естетичного розвитку. Негативний вплив подібного підходу виявляються в поширенні так званого «соматичного негативізму»: девальвації цінності тілесності в певних соціальних стратах, знецінення фізичного іміджу людини, відсутності соціального запиту на культивування тілесних якостей, байдужості до фізичного здоров'я, недовіри до тілесного досвіду і окремим сферам мистецтва, що оспівує тілесну красу. Другим негативним фактором є зворотне явище, так звана маргінальна «соматизація» людини (і окремих субкультур); це абсолютизація візуально-тілесних аспектів людини. Дослідження фізичної культури, що базується на принципах соматизации, виносить тілесні характеристики людини за межі кордонів культурної соціалізації; для даного підходу характерне апріорне виключення тілесності людини зі структури соціокультурних цінностей. Легко помітити, що обидві негативні тен- 
денції відображають зневажливе ставлення до тілесності. При цьому духовний, культурний та моральний зміст тілесної діяльності незмінно формується в процесі інкорпорування буття тілесності в структуру соціокультурних цінностей, норм та ідеалів. При цьому досягається відповідність тілесних показників індивіда його цілям і цінностям духовного, естетичного, морального і справді соціального розвитку. Формуються здібності і, головне, потреби використання людського тіла відповідно до етичної та естетичної платформи конкретних моделей культури. У концепті культурної антропології фізична культура постає як галузь культури, яка регулює діяльність людини, пов'язану з формуванням, розвитком і використанням тілесно-рухових здібностей людини відповідно до прийнятих в культурі (субкультурі) норм, цінностей і зразків.

\section{7. Висновки}

Філософсько-антропологічний аналіз феномену фізичної культури та спорту через поняття соматичного буття людини надає більш широкі можливості для розуміння та дослідження змісту, функцій та значення цих соціальних явищ у сучасному суспільстві, як з позиції особистості, так і соціуму.

Цілісне розуміння фізичного виховання полягає в тому, що це не тільки комплекси вправ і навантажень (бо це тільки засоби поліпшення фізичних тілесних показників), але реалізовані здібності і потреби індивіда до розвитку власної тілесності в співвідношенні 3 принципами культури, що включають розуміння цінності тіла i забезпечення відповідності тілесного розвитку моральному і естетичному базису (включаючи обрежне ставлення до тіла і здоров'я). Розуміння цінності фізичної культури змінює в суспільстві ставлення до фізичного виховання. Фізична культура набуває нового значення, вона повинна стати способом збереження фізичної активності, зміцнення здоров'я та збереження якості життя. Сучасна система фізичної підготовки людини, як частина фізкультурно-оздоровчої діяльності в цілому, повинна являти собою спеціальний комплекс соціально-економічних, політичних, юридичних, екологічних, культурно-виховних та інших заходів, спрямованих на збереження і поліпшення здоров'я, підвищення рівня фізичного розвитку і фізичної підготовленості людей. 


\section{Physical culture in somatic human being}

\section{Список літератури:}

1. Визитей Н.Н. Физическая культура личности: проблема человеческой телесности: методологические, социально-философские аспекты. - Кишинев: Штиинца, 1989. - 107 с.

2. Газнюк Л.М. Соматичне бутя персонального світу особистості. Монографія. Харків: ХДАФК, 2003. - 356 с.

3. Газнюк Л.М. Філософські етюди екзистенціально-соматичного буття. Монографія. - К.: ПАРАПАН, 2008. - 368 с.

4. Ибрагимов М.М. Сова Міневри і Аполлон: філософське есе про спорт. К.: ТОВ «НВП» Інтерсервіс», 2013. - 320 с.

5. Ибрагимов М.М. Философия спорта как новый антропологический проект: монография. К.: НУФВСУ. Изд-во «Олимпийская литература» 2014. $296 \mathrm{c}$.

\section{References:}

1. Vyzytei N.N. (1989) Fyzycheskaia kultura lychnosty: problema chelovecheskoi telesnosty: metodolohycheskye, sotsyalno-fylosofskye aspekty [Physical culture of the individual: the problem of human corporeality: methodological, social and philosophical aspects]. Kyshynev: Shtyyntsa. (in Russian)

2. Gazniuk L.M. (2003) Somatychne butia personalnoho svitu osobystosti. Monohrafiia [Somatic being of the personal world of personality. Monograph]. Kharkiv: KhDAFK. (in Ukrainian)

3. Gazniuk L.M. (2008) Filosofski etiudy ekzystentsialno-somatychnoho buttia. Monohrafia [Philosophical sketches of existential-somatic being. Monograph]. Kiyv: PARAPAN. (in Ukrainian)

4. Ybrahymov M.M. (2013) Sova Minevry i Apollon: filosofske ese pro sport [Minevra's Owl and Apollo: a philosophical essay about sport]. Kiyv: TOV "NVP" Interservis". (in Ukrainian)

5. Ybrahymov M.M. (2014) Fylosofyia sporta kak novыi antropolohycheskyi proekt: monohrafyia [The philosophy of sport as a new anthropological project: monograph]. Kiyv: NUFVSU. Yzd-vo "Olimpiyskaya literatura". (in Russian) 